\title{
Population of Pups and Food Reserves in Hives of Melipona Beecheii Rational Bennett as Basic Factors for their Health
}

\author{
José Andrés Martínez Machado*, Juan Pablo González Placeres, José Miguel Navarro Varela, Mario \\ Vazquez of Nuez, Eligia of Charity Cuellar Valero and Queen D Reyna Reyes \\ University of Cienfuegos, Cuba \\ *Corresponding author: José Andrés Martínez Machado, University of Cienfuegos, Cuba
}

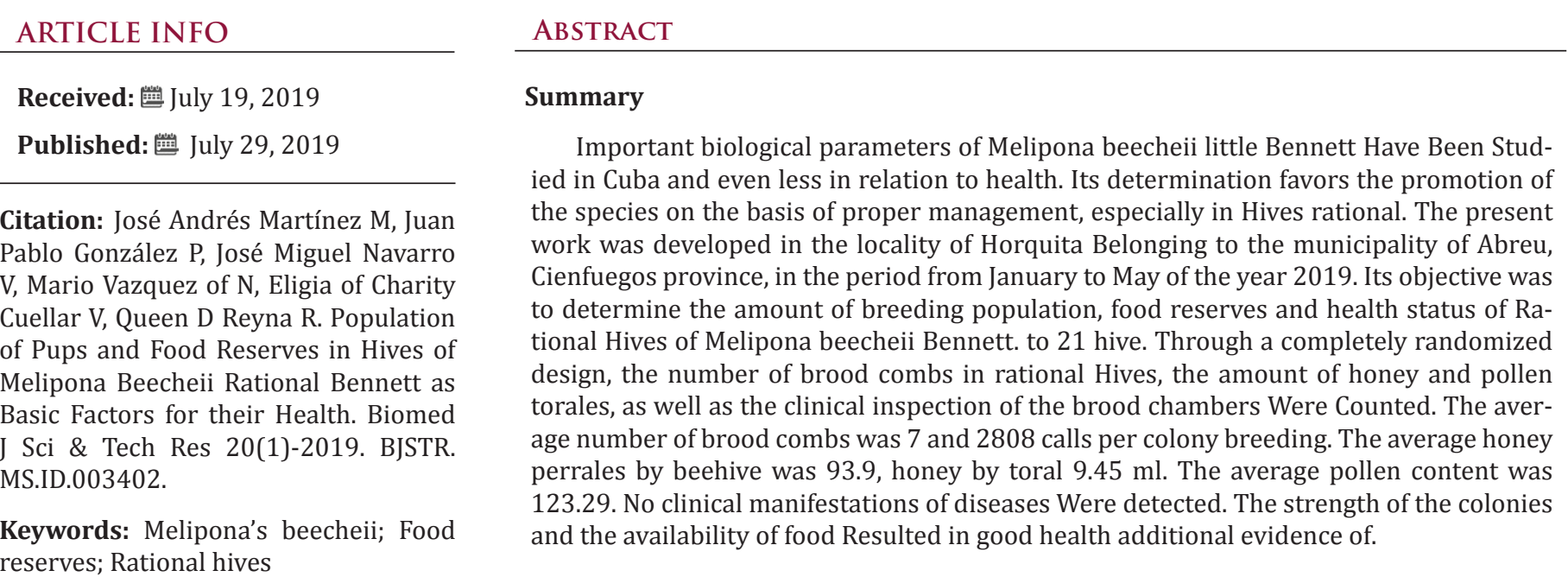

\section{Introduction}

The Meliponini or stingless form a group of about 500 species described worldwide number could be increased due to the existence of cryptic species (high morphological similarity) and the absence of detailed analysis in most genera [1]. They play an important role in the pollination of many species of wild and cultivated plants, and it has been estimated that 30 to $50 \%$ of the plants in the lowlands of tropical America are pollinated by bees of this group [2]. Cultivation of native stingless is an alternative to the management of AHB in tropical and subtropical areas activity. Although they belong to the same family, they are of a different kind, such that the incorporation of African genes is given within species stingless. Therefore, the exploitation of native bees could take nearbedroom houses places without danger, and with the possibility of obtaining an income [3].

Bees have a great relationship with our daily lives; along with butterflies and bats, they are responsible for pollinating about
$35 \%$ of crops that provide us with food. They pollinate many plant species from both temperate and tropical forests and our gardens and backyards, and in the case of Apis and stingless bees (Meliponini tribe) took advantage of products such as honey and wax. They are also present in many cultural aspects, for example, have been sacred emblems of ancient civilizations like the Maya and the Egyptians, they are subject of poems and songs, like the popular bachata "Like a bee to honey." Still, much of its ecology, diversity and importance remain unknown (González-Vanegas, 2018). In Cuba we have worked very little in the domestication of Meliponas rather have largely disappeared from the national territory and abundant only in places with thick vegetation, while they are virtually absent in urban and suburban locations.

The development of Meliponiculture could help maintain the species and increase their populations to provide pollination services and honey production, becoming a healthy and attractive 
occupation for many people regardless of age or gender, however, now prime weakness; know how to handle these insects as beneficial [4]. melipona beecheiilt is one of two species of eusocial bees in Cuba and is of interest for its honey and pollen, as well as the pollination of wild and cultivated plants. Biometric parameters have been studied in detail in countries like Costa Rica and Mexico [5,6]; but in Cuba are insufficient references of previous studies providing elements on the size of the population of the colonies and their food stocks. The aim of this study is to determine the oblation of baby food stocks and rational hives Melipona beecheii Bennett as basic factors for their health.

\section{Materials and Methods}

The study was conducted from January to May 2019, three meliponaries (Center Bees; Racking and Development Center and Meliponary Base), belonging to the Company Crops Several Horquita, the municipality of Abreus. A descriptive study for a completely randomized design for each meliponary. We worked with 21 housed in beehives rational type (PNN 1975) colonies, seven in each group. Each colony was determined the number and diameter of honeycombs offspring, the amount of food stocks torales (honey and pollen); as well as the health of rational hives. Honey samples were extracted with a $50 \mathrm{ml}$ syringe using a plastic catheter and placed in a $100 \mathrm{ml}$ graduated cylinder. For processing test data Kolmorov and a descriptive statistical analysis with Stat graphics Plus version 5.1 package was performed.

\section{Results and Discussion}

\section{Analysis of Reproductive Parameters of the Species Melipona Beecheii}

The range broodcombs by hives (Table 1) was greater for average Meliponary 1, while the lowest was for Meliponary 2. The average number of colony honeycombs was $7.29 \pm 6.43$ with ranges between 5 and 9, while a study by Fernandez and Navarro (2015), in 15 colonies of the People's Council Horquita, municipality Abreus, Cienfuegos province, showed that the number of these combs found in all hives coincided with those reported by Boggino [7] for Stingless bees (6-8 honeycombs hive); on the other hand they are different from the data found in the species Melipona beecheii Bennett (1831) in Yucatan, Mexico (8-12 honeycombs per hive) (Gonzalez, 2008). According total broodcombs found in hives 21 (Figure 1), 40.23\% were new (a), 52.18\% old or peduncles (b), and mixed $10.41 \%$ (c); Similar results are reported in the municipality of San Jose de las Lajas, Mayabeque province by Loriga (2015) who of all brood combs found in 12 beehives reported $34.43 \%$ were new, old or $49.18 \%$ cocoon, and $16.39 \%$ mixed; but does not coincide with the next results in Mexico with $40 \%$ of new cells and $60 \%$ of cells cocoon.
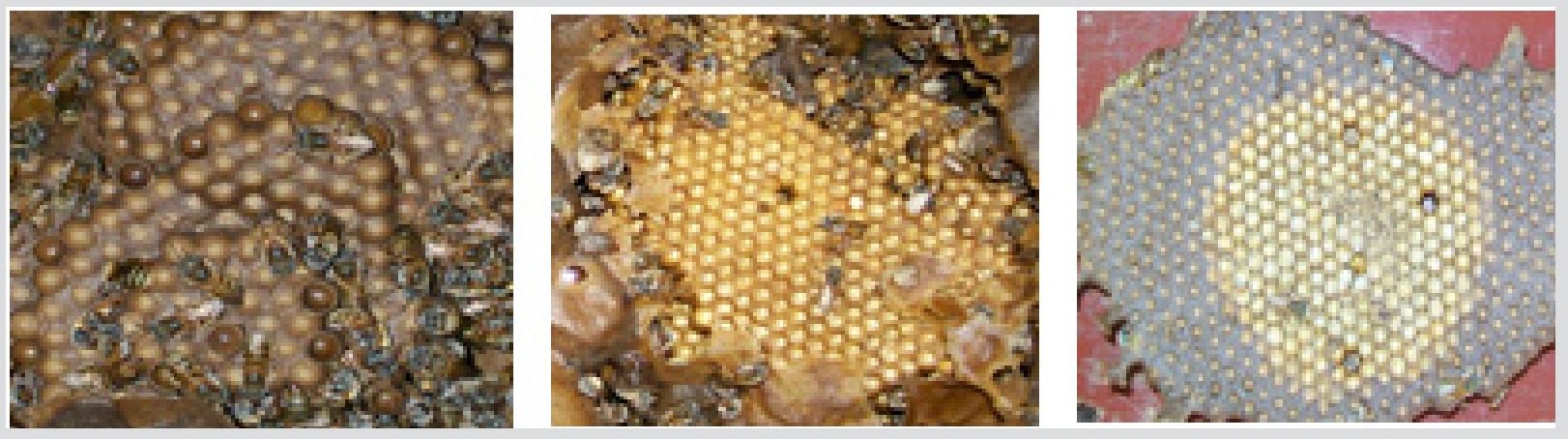

Figure 1: Representation of honeycombs offspring. a) new honeycombs. b) old honeycombs. c) mixed honeycombs.

Table 1: Reproductive parameters of the species Melipona beecheii.

\begin{tabular}{|c|c|c|c|c|c|c|c|}
\hline meliponaries & $\begin{array}{c}\text { Type } \\
\text { honeycomb }\end{array}$ & $\begin{array}{c}\text { No. honeycombs } \\
\text { (Average) }\end{array}$ & \% & $\begin{array}{c}\text { Diameter honeycomb } \\
\text { (Average cm) }\end{array}$ & $\begin{array}{c}\text { Diaper area } \\
\text { (Average } \mathbf{c m}^{2} \text { ) }\end{array}$ & $\begin{array}{c}\text { Number of young per } \\
\text { colony (Average) }\end{array}$ & $\begin{array}{c}\text { \% } \\
\text { (Avel }\end{array}$ \\
\hline one & PNN (1975) & 7.29 & 37.5 & 13.57 & 97.85 & 3189 & 39.34 \\
\hline two & PNN (1975) & 6.43 & 33.09 & 12.43 & 97.64 & 2820 & 34.78 \\
\hline 3 & PNN (1975) & 6.67 & 29.41 & 7 & 79.07 & 2447 \\
\hline
\end{tabular}

Immature population (from egg to imago emergency) averaged 2793/ Hive, ranging between 1830 and 3812 cells. Similar results (2135 offspring per colony) were reported by studying 19 colonies of M. beecheii in Costa Rica (Loriga, 2015), while in Yucatan, averages $40 \%$ and $60 \%$ were found and others [8] reported values of $30 \%$ and $70 \%$, but the species Nannotrigona perilampoides Cockerell. According Hliario et al. [9], the diameter of the brood combs provides a good idea of the overall condition of the colonies. Figure
2 shows that the hives meliponary 1 as trend had breeding areas with larger diameters. Roubik [10] states that the reproduction of the colonies is strongly determined by the availability of flowers, abundant pollen and building materials in the environment. This approach justifies the fact that the beehives busiest flight for collecting resources, in this case pollen, honeycombs present in greater numbers and with greater diameters. 

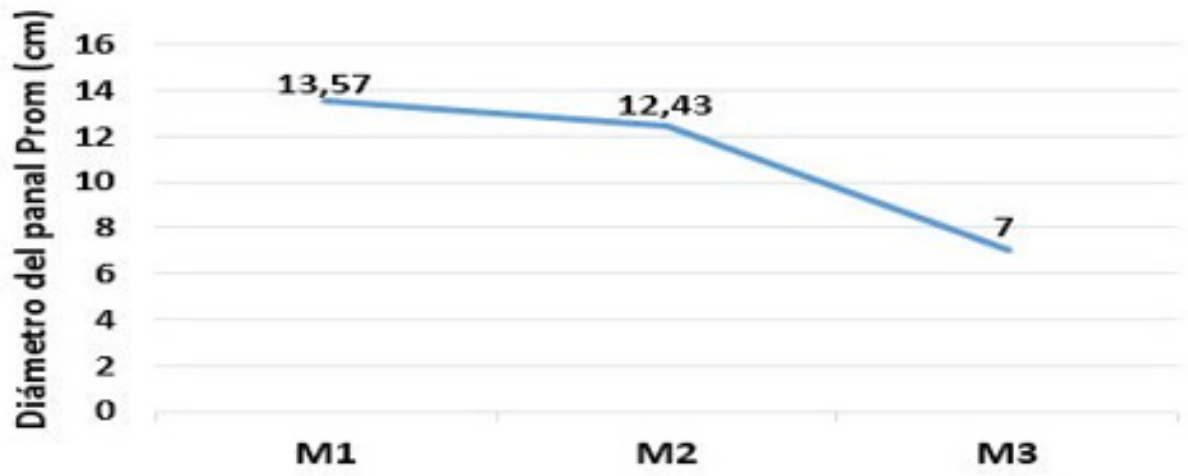

Cantidad de Meliponarios

Figure 2: Diameter breeding area.

Alvarez (2013) characterizing hives potentiated two queens (strong) and comparing this with a single queen hives (less strong) found that the first built honeycombs as many second and similar diameters. It should be considered, in the brood chamber, cloistered in a limited and bordered space primarily by torales pollen, once the brood combs occupy all available space, building cells slows down and the growth rate new combs decreases to be limited by the space at a lower rate is being created at the bottom, which shifts the proportion of types of breeding for bud cells. Clearly this area on the development and composition of the colony remains almost virgin and will require more than others, future studies (Loriga 2015). Figure 3 shows that the strongest hives, as a trend, had higher number of offspring per hive.

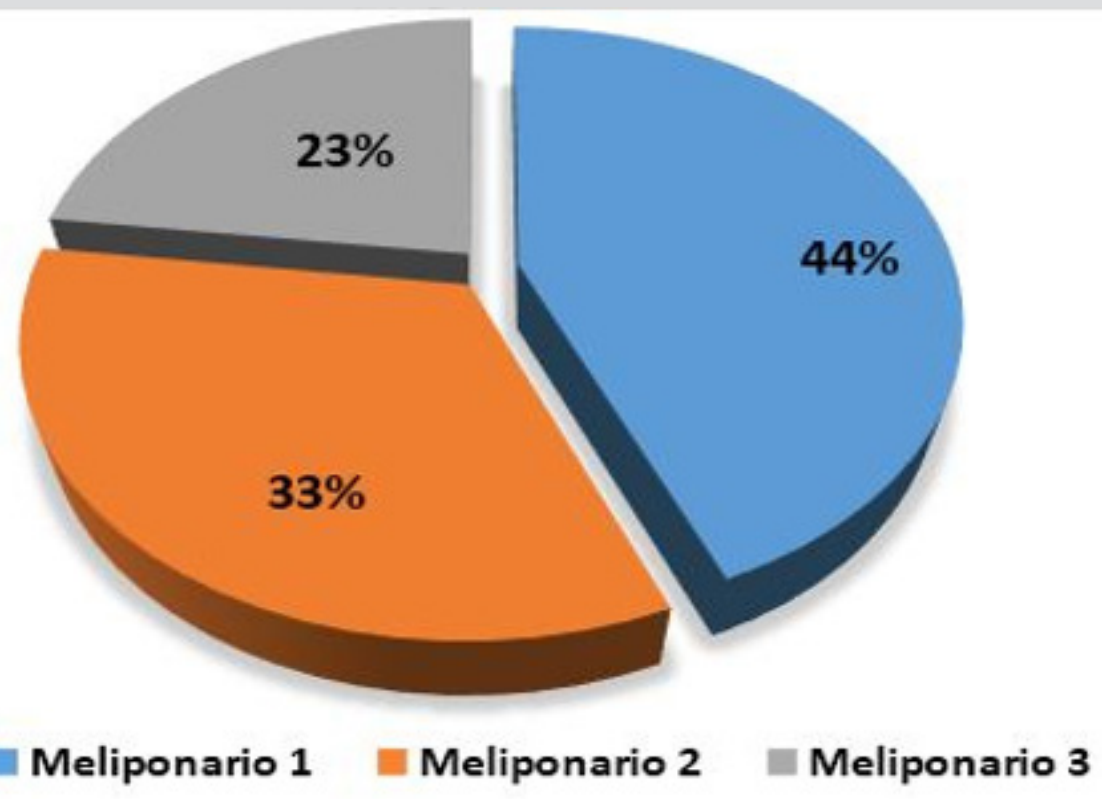

Figure 3: Number of young per hive.

\section{Analysis of the Amount of Food Reserves}

In Table 2 the results are reported in terms of food stocks, in this aspect it showed large variability in the amount of torales between meliponaries studied with an average of 657.33 torales honey and 205.67 torales pollen and a total of 2589 torales. In meliponary 1 Most torales of honey and pollen was observed because its surroundings there is a greater amount of bloom for the collection of food stocks and structure meliponary 1 is better able than the 2 and 3 . Productions of honey per hive are highly variable and influenced by numerous factors such as the amount of floral resource, the size of the accommodations, the strength of the colony (Carrillo 1998) and health status Green et al. (2013). The 
average amount of pollen torales was variable (Table 3), lower than those obtained by another author in Costa Rica (Van Veen 1999). This reflects the floristic little resort in the middle and low capacity for collecting colonies studied.

Table 2: Amount of food reserves by meliponary.

\begin{tabular}{|c|c|c|c|}
\hline meliponary & Total torales & $\begin{array}{c}\text { Torales amount of } \\
\text { honey }\end{array}$ & $\begin{array}{c}\text { Torales amount } \\
\text { of pollen }\end{array}$ \\
\hline one & 998 & 766 & 232 \\
\hline two & 696 & 570 & 126 \\
\hline 3 & 895 & 636 & 259 \\
\hline Half & 863 & 657.33 & 205.67 \\
\hline Total & 2589 & 1972 & 617 \\
\hline
\end{tabular}

Table 3: Performance hives honey and pollen.

\begin{tabular}{|c|c|c|c|c|}
\hline Parameters $(\mathbf{n}=\mathbf{2 1})$ & $\mathbf{X}$ & Min. & Max. & DS \\
\hline Torales of honey per hive & 93.9 & 40 & 157 & 29,339 \\
\hline Amount of honey per hive $(\mathrm{ml})$ & 9.45 & 7 & eleven & 1.15 \\
\hline Torales pollen per hive & 29.38 & 5 & 57 & 15.68 \\
\hline
\end{tabular}

The amount of reserves of food (honey and pollen) is associated with the strength of the colony, species, foraging activity, weather factors, flight activity and potential competitors, and health status (Green, 2013). Moreover, the relationship between food reserves and production of sexed individuals has already been reported in the species [11], And to decrease the amount of food, especially pollen, it decreases the production of individuals, particularly drones, which also occurs in a reduction in body sizeand sperm production (Pech-May, 2012). Something similar was observed in Melipona flavolineata Friese, regarding the size of the workers (Veiga, 2013). Data on the breeding population and food stocks shown in this work are the first references to these parameters where an average of $93.90 \pm 29.33$ torales of honey per hive (Table 3 ), ranging between 40 and 157 torales reached that containing this food. an average yield of honey was obtained by colony $123.29 \mathrm{ml}$ with ranges 45 and $210 \mathrm{ml}$. The average amount of honey per toral was $7 \mathrm{ml}$ with ranges between (7 and $11 \mathrm{~mL}$ ).

In Mexico yields $600 \mathrm{ml}$ of honey per hive (Carrillo, 1998) was reached, while in Costa Rica the average was $151 \mathrm{ml}$ studying 19 colonies before the nectar flow and to quantify the biological reserves of the species Melipona beecheii Bennett (Apidae: Meliponini) in Cuba, and play an important role in the development and functionality of the colony, as well as lay a foundation for further studies in this field. As for the performance of honey and pollen from beehives was matched samples reported by Fernandez and Navarro (2015), where there were no statistically significant differences in classifying the hives as strong, which according to flight activity tended to store more honey, pollen and propolis than average and weak. These reserves are vital for the reproduction of the colony. Pollen is important for the full development of larvae main source of protein and vitamins, newly emerged bees and queen. Honey is produced by bees from the nectar collected in flowers and processed by digestive enzymes such insects, being stored in drums to serve food [12]. Apartir these elements bees produce liquid larval food, pollen mixture and glandular secretion brown-dark and strong sour taste coloration [10] that is placed in the brood cells for the development of the larvae after the egg deposited by the queen, eclosiona.

\section{Analysis of the Health of Hives}

The health of hives is in good condition because in terms of the number of honeycombs have an average number of 7 per hive in the three meliponaries, allowing us to propose that the colonies are in phase \# 2 [4]. There is a satisfactory amount of food reserves by meliponaries. During the study it found that most of hives occupied all internal living space, causing limitations in the construction of honeycombs pups (Figure 4). In all colonies constant internal activity (Figure 5) which caused satisfactory data were obtained both in the number of honeycombs offspring and food reserves evidenced. good structuring of the colonies was also observed, thanks to good care and maintenance worker who studied hives. Inspection of the brood chamber and food torales to evidence the absence of clinical manifestations of disease. Either larvae or adults arthropod parasites were found, all of which, combined with the large population, good strength and existing food stocks, express the good health of the colonies studied.

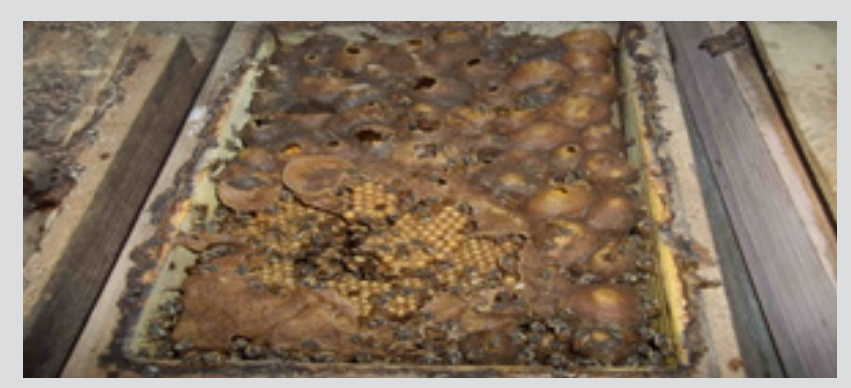

Figure 4: Internal living space of the hive.

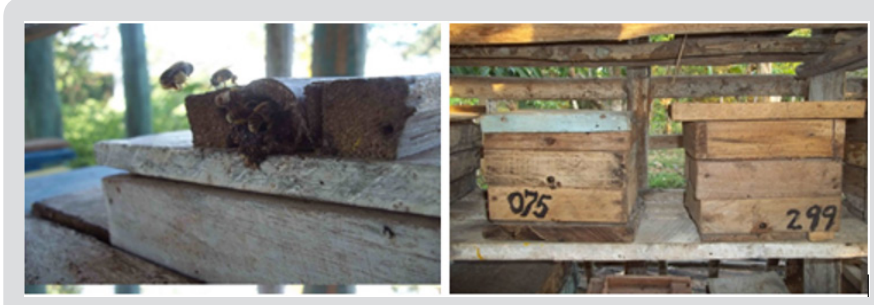

Figure 5: Bee activity and structure of the hive.

\section{Conclusions}

1. No differences between meliponaries in the number of broodcombs by rational hives Meliponas beecheii, total honeycombs offspring was 141 with an average of $6.43 \pm 7.29$ with ranges between 5 and 9 .

2. The living space per hive reached maximum capacity for meliponaries study, the number of reserve food torales was 2589 (honey and pollen), a yield of honey was obtained by colony $123.29 \mathrm{ml}$ ranges between 45 and $210 \mathrm{ml}$. 
3. The availability of brood combs and food reserves significantly influence health status colony Meliponas beecheii Bennett.

\section{Recommendations}

a. Continue the study of biology and architecture bee nests land (Melipona beecheii Bennett.) And pollinating activity.

\section{References}

1. Alvarez Dalia (2013) Racking enhanced for reproductive and productive Meliponas increase. Undergraduate thesis, University of Cienfuegos "Carlos Rafael Rodriguez". Hundred fires, Cuba.

2. Nogueira Neto $P$ (1997) Criação life and indigenous abelhas sem Ferrão. São Paulo. Brazil: Editora Nogueirapis.

3. Van Veen JW (1999) Characteristics of colony Nest and log hived Melipona beecheii (Apidae; Meliponini). J BeeKeeper Res 38: 43-48.

4. Vázquez M, Almeida H, Navarro JM, Yanes Neibys, Febles H, et al. (2011). Bee breeding technology Earth (Melipona beechii Bennett, 1831). Miscellaneous Crops Enterprise Horquita. Hundred fires, Cuba.

5. JA Gonzalez Acereto (2008) Autonomous University of Yucatán. Breeding and management of stingless bees native in Mexico. Merida Yucatan Mexico pp. 177.

\section{ISSN: 2574-1241}

DOI: $10.26717 /$ BJSTR.2019.20.003402

José Andrés Martínez M. Biomed J Sci \& Tech Res

This work is licensed under Creative Commons Attribution 4.0 License

Submission Link: https://biomedres.us/submit-manuscript.php
6. Breastplate W, D Alvarez L Fonte, Demedio J (2015) Immature population and food stocks in natural colonies of Melipona beecheii Bennett (Apidae: Meliponini) as basic factors for their health. Rev Anim Health 37(1): 47-51.

7. Boggino PA (2008) Native bees endangered. Rural supplement.

8. Chuc G (2005) Characterization of three species nests of stingless bees (Hymenoptera: Meliponini) Yucatan. Diploma work, Merida Yucatan.

9. Hilario SD, Empress Fonseca VL, Kleinert A (2000) Flight activity and colony strength in the stingless bee Melipona bicolor bicolor (Apidae, Meliponinae). Revista Brasileira de Biology 60(2): 299-306.

10. Roubik DW (1989) Ecology and Natural History of Tropical Bees. Cambridge Tropical Biology Series: University Press, New York, USA.

11. Moo Valle H, Quezada Ruan JJ, Song J, González JA (2004) Caste ontogeny and the distribution of reproductive cells on the combs of Melipona beecheii (Apidae: Meliponini). Apidologie 35(6): 587-594.

12. Carvalho Zilse, Gislene Porto, THE Nunes da Silva, CG Costa Pinto, Maria de Fatima (2007) Atividades Voo of Operarias of Melipona seminigra (Hymenoptera: Apidae) in an agroforestry system da Amazônia. Uberlandia 23 (1): 94-99.

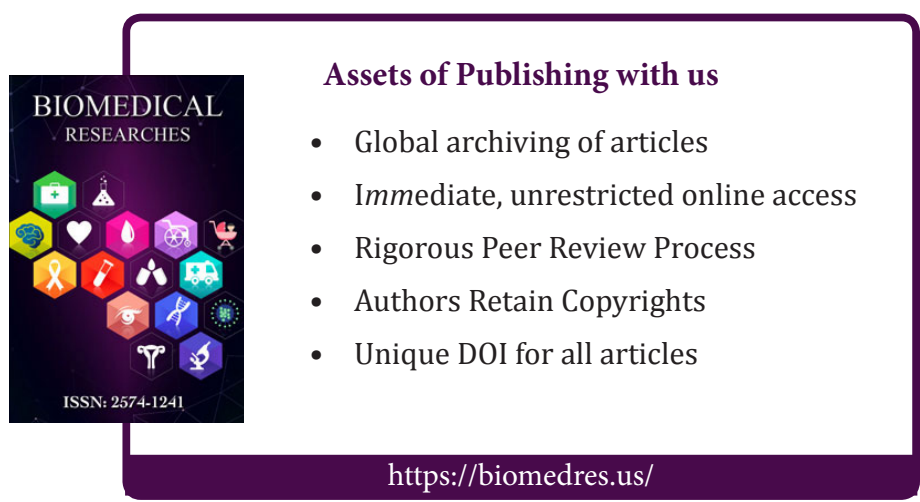

